CANADA AT WAR

Conscription, Diplomacy, and Politics 



\title{
CANADA AT WAR
}

\section{Conscription, Diplomacy, and Politics}

\author{
J.L. GRANATSTEIN
}


(C) University of Toronto Press 2020

Toronto Buffalo London

utorontopress.com

Printed in Canada

ISBN 978-1-4875-0705-3 (cloth)

ISBN 978-1-4875-2476-0 (paper)

ISBN 978-1-4875-3547-6 (EPUB)

ISBN 978-1-4875-3546-9 (PDF)

\section{Library and Archives Canada Cataloguing in Publication}

Title: Canada at war : conscription, diplomacy, and politics / J.L. Granatstein. Names: Granatstein, J. L., author.

Description: Includes bibliographical references and index.

Identifiers: Canadiana (print) 20200278274 | Canadiana (ebook) 20200278339

| ISBN 9781487507053 (cloth) | ISBN 9781487524760 (paper) | ISBN

9781487535476 (EPUB) | ISBN 9781487535469 (PDF)

Subjects: LCSH: World War, 1914-1918 - Canada. | LCSH: World War, 1939-

1945 - Canada. | LCSH: King, William Lyon Mackenzie, 1874-1950. | LCSH:

Draft - United States - History - 20th century. | LCSH: Canada - Politics and government - 1914-1945. | LCSH: Canada - Foreign relations - 1914-1945.

Classification: LCC FC163 .G73 2020 | DDC 971.062/2 - dc23

Every effort has been made to obtain permissions for the reprinted material in this book. Any oversights brought to the attention of the publisher will be rectified in all future printings of the book.

University of Toronto Press acknowledges the financial assistance to its publishing program of the Canada Council for the Arts and the Ontario Arts Council, an Ontario government agency.

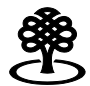

Canada Council for the Arts
Consell des Arts

du Canada

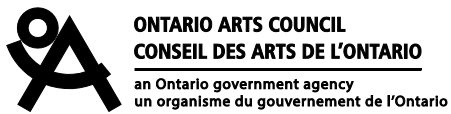

Funded by the Financé par le Government gouvernement of Canada du Canada 